\title{
The fasting metabolism of cattle
}

\author{
By K. L. BLAXTER* AND F. W. WAINMAN* \\ Hannah Dairy Research Institute, Ayr \\ (Received 20 August 1965-Accepted 3 November 1965)
}

\begin{abstract}
$x$. The metabolism of seventeen steers was determined on forty-nine occasions during fasts of either $\mathrm{I}_{12}$ or $\mathrm{I}_{3} 6 \mathrm{~h}$ duration. 2 . Faeces continued to be produced during fasts of up to $136 \mathrm{~h}$ duration at rates which were $15-20 \%$ of those noted before the fasts began. 3 . Carbon dioxide production and oxygen consumption fell continuously throughout with animals weighing less than $200 \mathrm{~kg}$ but changed little after $88 \mathrm{~h}$ in animals weighing more than $200 \mathrm{~kg}$. Methane production was considerably reduced during fasting but did not disappear. Urinary nitrogen excretion changed very little. Of the total loss of energy from the body, the loss of protein accounted for $25 \%$. This was unaffected by age or size of animal. 4 . With individual Ayrshire steers, metabolism increased during growth with body-weight raised to the power $0.68 \pm 0.05$. No greater precision of estimate was obtained from logarithmic regressions of metabolism on body-weight than from linear ones. 5. Seven Ayrshire steers had a mean fasting metabolism of $100 \pm \mathrm{r} \cdot 6 \mathrm{kcal} / \mathrm{kg} W^{0.73} 24 \mathrm{~h}$, eight Black cattle of the Aberdeen Angus type a fasting metabolism of $8 \mathrm{I} \pm \mathrm{r}^{\cdot} 5 \mathrm{kcal} / \mathrm{kg} W^{0 \cdot 73} 24 \mathrm{~h}$ and two Ayrshire $\times$ Beef Shorthorn steers a fasting metabolism of $96 \pm 2.9 \mathrm{kcal} / \mathrm{kg} W^{0.73} 24 \mathrm{~h}$. Variation in the fasting metabolism of an individual steer from time to time, expressed as a coefficient of variation, was $\pm 7.4 \%$. 6. The results are discussed in relation to interspecies generalizations about the relation between fasting metabolism and bodyweight.
\end{abstract}

According to Ritzman \& Benedict (1938), the first determinations of the fasting metabolism of steers were made by them in 1919 at Durham, New Hampshire, and in the following year Armsby conducted similar experiments with cows in the respiration calorimeter at the State College, Pennsylvania. Relatively few determinations of the fasting metabolism of cattle have been made in the ensuing 45 years, largely because few laboratories have been equipped with calorimeters or respiration chambers. The determinations made by Ritzman \& Benedict (1938), by Kleiber, Regan \& Mead (1945), by Forbes and his associates (Forbes, Fries, Braman \& Kriss, 1926; Forbes, Kriss \& Braman, I927; Forbes, Swift, Bratzler, Black, Wainio, Marcy, Thacker \& French, I94I; Cochrane, Fries \& Braman, 1925) and by Mitchell and his associates (Mitchell, Hamilton \& Haines, 1940, 194r; Mitchell, Hamilton, McClure, Haines, Beadles \& Morris, 1932) were relatively few, and for the most part did not embrace a wide range of size or breed of cattle. The results of the fifty-eight determinations traced as having been made up to 1962 were summarized by Blaxter (1962). Extensive observations made by Benedict \& Ritzman (1927) with four steers were not included because oxygen consumption was not determined, heat production being calculated from carbon dioxide production using an assumed respiratory quotient. Brody's (1945) determinations of resting metabolism by short-term measurement of the respiratory exchange helped, however, to delineate effects of age and breed on metabolism. Since that summary was made workers in Japan (Hashizume, Kaishio, Ambo, Morimoto, Masubuchi, Abe, Horii, Tanaka, Hamada \& Takahashi, I962; Hashizume, Morimoto,

* Present address: Rowett Research Institute, Bucksburn, Aberdeen. 
Masubuchi, Abe, Horii, Hamada, Tanaka, Takahashi, Kaishio \& Ambo, 1964) have made fifteen determinations of the basal metabolism of native cattle and six determinations of the metabolism of European-type cattle. In addition Flatt \& Coppock (1963) have briefly reported the results of a number of determinations with six cows. The total number of experiments to determine the fasting metabolism of cattle that have been traced to date is thus in the region of roo only. The purpose of this paper is to summarize the results of a further forty-nine determinations of the fasting metabolism of seventeen cattle with reference to the effects of age and breed. The results of some of these have been published (Blaxter \& Wainman, 1961 $a, b, 1964$; Blaxter, Wainman \& Davidson, I966); the remainder have not.

\section{EXPERIMENTAL}

Animals. Seventeen steers, including seven Ayrshire steers (nos. I, 2, 3, 4, 5, 6 and 7), two Ayrshire $\times$ Beef Shorthorn steers $(\mathrm{Kr}$ and $\mathrm{Bg}$ ) and eight Black cattle of the Aberdeen Angus type (As, Ay, C, E, F, I, J and H) were used. The animals were purchased from commercial sources. The Ayrshires were undoubtedly pure-bred but the Black cattle were not. Some of the latter, from their appearance, included Galloway blood and others had white flecking suggesting some further breed admixture in their ancestry. All the Black animals were, however, animals bred for beef production rather than as dairy animals. They are referred to as Black cattle. The number of determinations made with each varied, as can be seen from Table 4. With seven animals $(\mathrm{I}, 2,3,4,5, \mathrm{As}$ and Ay), four or more determinations were made at different times. While some animals were better subjects for respiration experiments than others, all were docile and appeared unaffected by the experimental conditions imposed.

Method of determination of fasting metabolism. Before the fast began all the animals were given a ration of hay or of hay and oats calculated to be sufficient to prevent them losing or gaining weight. They were given their last meals at $17.00 \mathrm{~h}$ on the day preceding the experiment. Metabolism measurements were commenced at $09.00 \mathrm{~h}$ the following day and continued either until $09.00 \mathrm{~h} 4$ days, or, in six experiments, 5 days later. In some but not all experiments with adult cattle, $3 \circ \mathrm{g} \mathrm{MgO}$ were given on the 2nd day of fast because of the finding by Robertson, Paver, Barden \& Marr (1960) that fasting can lead to hypomagnesaemia. No tetany was observed in animals not given $\mathrm{MgO}$, and the $\mathrm{MgO}$ can be assumed to have had no effect on metabolism. The environmental temperature at which the determinations were made was always $22^{\circ}$ or above and the air velocity was $0.4 \mathrm{miles} / \mathrm{h}$. This environment is well above the critical temperature of the steer (Blaxter \& Wainman, 196ra). On each day of the fast, carbon dioxide production, methane production and oxygen consumption were determined using closed-circuit respiration chambers. The steers were weighed at the beginning and end of the fasts and usually also after $64 \mathrm{~h}$ of fast. The fasting metabolism was taken to be the mean heat production per $24 \mathrm{~h}$ measured $64-112 \mathrm{~h}$ after food, a period referred to as the $3^{\text {rd }}$ and $4^{\text {th }}$ days of fast. The analytical and other methods were the same as those described for sheep (Blaxter, 1962). Two respiration chambers were used. That of Wainman \& Blaxter (1958) was used to measure the 
metabolism of animals weighing more than about $250 \mathrm{~kg}$, and the metabolism of smaller animals was determined in a closed-circuit respiration chamber operating on similar principles but with an animal chamber of 4000 1. capacity rather than the 90001 . of the larger instrument and in which $\mathrm{CO}_{2}$ was absorbed in a solution of potassium hydroxide rather than with solid soda lime.

\section{RESULTS}

Faecal excretion. As first reported for adult oxen by Grouven (1864), faeces continued to be produced throughout the fasts by all the animals. Table I shows the mean weights of dry faeces produced during fasting by cattle weighing $200 \mathrm{~kg}$ or less

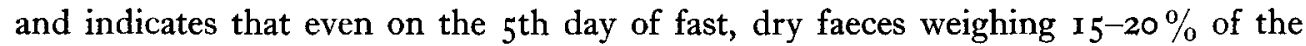
amounts excreted before the fast began were produced. As described for adult steers by Benedict \& Ritzman (1927), the moisture content of the faeces fell with increased length of fast and the faeces were usually in the form of pellets. The $\mathrm{N}$ content of the dry faeces changed very little with length of fast.

Table I. Mean excretion of dry matter and concentration of nitrogen in the faeces of young Ayrshire steers during fasting

\begin{tabular}{|c|c|c|c|c|c|c|c|c|}
\hline \multirow[b]{2}{*}{ Steers } & \multirow{2}{*}{$\begin{array}{c}\text { Age } \\
\text { (weeks) }\end{array}$} & \multirow{2}{*}{$\begin{array}{c}\text { Mean } \\
\text { body- } \\
\text { weight } \\
(\mathrm{kg})\end{array}$} & \multirow{2}{*}{$\begin{array}{l}\text { Before } \\
\text { fasting }\end{array}$} & \multicolumn{5}{|c|}{ Day of fasting } \\
\hline & & & & $\mathbf{I}$ & 2 & 3 & 4 & 5 \\
\hline \multicolumn{9}{|c|}{ Dry matter $(g / 24 h)$} \\
\hline $4,5,6$ & 16 & 70 & 494 & 149 & I 49 & 58 & 74 & - \\
\hline $4,5,7$ & 34 & 97 & 787 & 446 & 278 & I35 & I 6 & - \\
\hline $1,2,3$ & $3 I$ & 145 & $86_{5}$ & 372 & 224 & 182 & 191 & 135 \\
\hline $1,2,3$ & $4^{6}$ & 182 & 950 & 507 & 352 & 231 & 143 & 175 \\
\hline \multicolumn{9}{|c|}{$\% \mathrm{~N}$ in faeces } \\
\hline $4,5,6$ & 16 & 70 & 2.87 & 3.05 & $3 \cdot 21$ & $2 \cdot 89$ & 2.94 & - \\
\hline $4,5,7$ & 34 & 97 & $2 \cdot 34$ & $2 \cdot 37$ & $2 \cdot 45$ & 2.54 & 2.40 & - \\
\hline$I, 2,3$ & 31 & I 45 & $2 \cdot 84$ & $3 \cdot 12$ & 2.80 & $2 \cdot 74$ & $2 \cdot 44$ & 2.71 \\
\hline$I, 2,3$ & 46 & 182 & 2.90 & $2 \cdot 89$ & $2 \cdot 73$ & $2 \cdot 55$ & $2 \cdot 53$ & 2.51 \\
\hline
\end{tabular}

About a third of the weight loss in fasting cattle can be accounted for by a loss of digestive-tract contents, as demonstrated by the continued production of faeces. For example, steers I, 2 and 3 when fasted for 5 days at a body-weight of $160-170 \mathrm{~kg}$ produced respectively $6.0,5.8$ and $3.5 \mathrm{~kg}$ fresh faeces in the 5 -day period. Their weight losses during the same interval were $17 \cdot 7,21 \cdot 3$ and $12 \cdot 7 \mathrm{~kg}$ respectively.

Metabolism on successive days of fasting. Table 2 summarizes the results of twentyeight experiments made with Ayrshire steers, classified according to their weight after I $2 \mathrm{~h}$ of fast. $\mathrm{CO}_{2}$ production and $\mathrm{O}_{2}$ consumption fell continuously throughout the fasting periods in animals weighing less than $200 \mathrm{~kg}$, but with animals weighing more

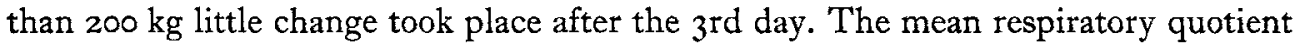
on the $3^{\text {rd }}$ and $4^{\text {th }}$ days of fasting was, with one exception, accounted for by a single aberrant value for $\mathrm{CO}_{2}$ production on the 3 rd day of fast, very close to 0.73 . Methane production fell throughout the fasts and on the $4^{\text {th }}$ day ranged from a mean of $4 \cdot 01 . / 24 \mathrm{~h}$ 
for animals weighing on average $79 \mathrm{~kg}$ to $7 \cdot 31 . / 24 \mathrm{~h}$ for animals weighing $345 \mathrm{~kg}$. The amounts of methane produced when the animals were given normal maintenance diets before they were fasted were about $80,130,170$ and $2201 . / 24 \mathrm{~h}$ for the four groups of animals weighing 50-100, 100-200, 200-300 and 300-400 kg respectively. On two occasions steers $\mathrm{I}, 2$ and 3 were each fasted for 5 days when they weighed less than $250 \mathrm{~kg}$. The mean amounts of $\mathrm{CH}_{4}$ produced on the $3^{\mathrm{rd}} 4^{\text {th }}$ and $5^{\text {th }}$ days were 6.65 , 3.95 and $2 \cdot 881 . \mathrm{CH}_{4} / 24 \mathrm{~h}$ respectively, which suggest a long continuance of $\mathrm{CH}_{4}$ production after cessation of feeding. Urinary $\mathrm{N}$ excretion changed very little during the course of the experiments in any of the groups.

Table 2. Metabolism of Ayrshire steers when fasted for $112 h$

\begin{tabular}{|c|c|c|c|c|c|c|c|}
\hline \multirow{2}{*}{$\begin{array}{l}\text { No. of } \\
\text { steers }\end{array}$} & \multirow{2}{*}{$\begin{array}{c}\text { Weight } \\
\text { range } \\
(\mathrm{kg})\end{array}$} & \multirow[b]{2}{*}{ Measurement } & \multicolumn{4}{|c|}{ Day of fast } & \multirow[t]{2}{*}{$\begin{array}{l}\text { Obser- } \\
\text { vations on } \\
\text { 4th day of } \\
\text { fasting } \\
\text { as a } \\
\text { percentage } \\
\text { of those } \\
\text { on the Ist }\end{array}$} \\
\hline & & & $\mathbf{I}$ & 2 & 3 & 4 & \\
\hline 5 & $50-100$ & $\begin{array}{l}\mathrm{O}_{2} \text { consumption }(1 / 24 \mathrm{~h}) \\
\mathrm{CO}_{2} \text { production }(1 . / 24 \mathrm{~h}) \\
\mathrm{CH}_{4} \text { production }(1 / 24 \mathrm{~h}) \\
\text { Urine } \mathrm{N}(\mathrm{g} / 24 \mathrm{~h}) \\
\text { Body-weight }(\mathrm{kg}) \\
\text { Heat production }(\mathrm{kcal} / 24 \mathrm{~h}) \\
\text { Respiratory quotient }\end{array}$ & $\begin{array}{r}645 \cdot 4 \\
530 \cdot 4 \\
17 \cdot 7 \\
23 \cdot 1 \\
86 \cdot 1 \\
3089 \\
0.822\end{array}$ & $\begin{array}{r}588 \cdot 5 \\
449 \cdot 1 \\
8 \cdot 7 \\
22 \cdot 1 \\
82 \cdot 6 \\
2778 \\
0 \cdot 763\end{array}$ & $\begin{array}{r}544 \cdot 6 \\
399 \cdot 4 \\
5 \cdot 6 \\
18 \cdot 5 \\
81 \cdot 0 \\
2555 \\
0 \cdot 733\end{array}$ & $\begin{array}{r}519 \cdot 5 \\
376 \cdot 3 \\
4 \cdot 0 \\
18 \cdot 5 \\
79 \cdot 2 \\
2432 \\
0.724\end{array}$ & $\begin{array}{l}80 \cdot 2 \\
70 \cdot 9 \\
22 \cdot 5 \\
80 \cdot 0 \\
92 \cdot 0 \\
78 \cdot 7 \\
-\end{array}$ \\
\hline 8 & $100-200$ & $\begin{array}{l}\mathrm{O}_{2} \text { consumption }(1 . / 24 \mathrm{~h}) \\
\mathrm{CO}_{2} \text { production }(1 / 24 \mathrm{~h}) \\
\mathrm{CH}_{4} \text { production }(1 . / 24 \mathrm{~h}) \\
\text { Urine } \mathrm{N}(\mathrm{g} / 24 \mathrm{~h}) \\
\text { Body-weight }(\mathrm{kg}) \\
\text { Heat production }(\mathrm{kcal} / 24 \mathrm{~h}) \\
\text { Respiratory quotient }\end{array}$ & $\begin{array}{r}\text { I I04.I } \\
903 \cdot 6 \\
31 \cdot 6 \\
26 \cdot 9 \\
\text { I69.2 } \\
5274 \\
0.818\end{array}$ & $\begin{array}{r}985 \cdot 5 \\
756 \cdot 0 \\
13 \cdot 4 \\
28 \cdot 5 \\
163 \cdot 5 \\
4648 \\
0.767\end{array}$ & $\begin{array}{r}902 \cdot 8 \\
661 \cdot 0 \\
6 \cdot 8 \\
27 \cdot 9 \\
160 \cdot 7 \\
4221 \\
0.732\end{array}$ & $\begin{array}{r}868 \cdot 2 \\
607 \cdot 0 \\
4 \cdot 2 \\
23 \cdot 8 \\
158 \cdot 3 \\
4062 \\
0 \cdot 700\end{array}$ & $\begin{array}{l}78 \cdot 6 \\
67 \cdot 2 \\
13 \cdot 3 \\
88 \cdot 5 \\
93 \cdot 6 \\
77 \cdot 0 \\
\end{array}$ \\
\hline 8 & $200-300$ & $\begin{array}{l}\mathrm{O}_{2} \text { consumption }(1 . / 24 \mathrm{~h}) \\
\mathrm{CO}_{2} \text { production }(1 . / 24 \mathrm{~h}) \\
\mathrm{CH}_{4} \text { production }(1 . / 24 \mathrm{~h}) \\
\text { Urine } \mathrm{N}(\mathrm{g} / 24 \mathrm{~h}) \\
\text { Body-weight }(\mathrm{kg}) \\
\text { Heat production }(\mathrm{kcal} / 24 \mathrm{~h}) \\
\text { Respiratory quotient }\end{array}$ & $\begin{array}{r}1342 \cdot 5 \\
1182 \cdot 8 \\
50 \cdot 0 \\
42 \cdot 4 \\
249.5 \\
6518 \\
0.881\end{array}$ & $\begin{array}{r}1214.6 \\
914.5 \\
17.6 \\
49.0 \\
240.5 \\
5720 \\
0.753\end{array}$ & $\begin{array}{r}\mathrm{I} 35 \cdot 2 \\
811 \cdot 4 \\
9 \cdot 8 \\
50 \cdot 6 \\
- \\
5306 \\
0.715\end{array}$ & $\begin{array}{r}\text { I I } 37 \cdot 7 \\
822 \cdot 8 \\
6 \cdot 1 \\
43 \cdot 0 \\
234 \cdot 5 \\
5321 \\
0.723\end{array}$ & $\begin{array}{r}84 \cdot 7 \\
69 \cdot 6 \\
12 \cdot 2 \\
101 \cdot 4 \\
94 \cdot 0 \\
81 \cdot 6 \\
\end{array}$ \\
\hline 7 & $300-400$ & $\begin{array}{l}\mathrm{O}_{2} \text { consumption }(1 . / 24 \mathrm{~h}) \\
\mathrm{CO}_{2} \text { production }(1 . / 24 \mathrm{~h}) \\
\mathrm{CH}_{4} \text { production }(1 . / 24 \mathrm{~h}) \\
\text { Urine } \mathrm{N}(\mathrm{g} / 24 \mathrm{~h}) \\
\text { Body-weight }(\mathrm{kg}) \\
\text { Heat production }(\mathrm{kcal} / 24 \mathrm{~h}) \\
\text { Respiratory quotient }\end{array}$ & $\begin{array}{r}1773 \cdot 3 \\
1698 \cdot 8 \\
54 \cdot 0 \\
51 \cdot 4 \\
365 \cdot 3 \\
8794 \\
0.958\end{array}$ & $\begin{array}{r}623 \cdot 5 \\
\times 334 \cdot 0 \\
21 \cdot 7 \\
53 \cdot 0 \\
772 \\
0.821\end{array}$ & $\begin{array}{l}\text { I } 495 \cdot 6 \\
\text { I I } 79 \cdot 6^{*} \\
\text { Ir } 3 \\
46 \cdot 8 \\
- \\
7230 \\
0.788^{*}\end{array}$ & $\begin{array}{r}\text { I } 503 \cdot 1 \\
1096 \cdot 6 \\
7 \cdot 3 \\
50 \cdot 6 \\
344.9 \\
7052 \\
0.729\end{array}$ & $\begin{array}{l}84 \cdot 8 \\
64 \cdot 6 \\
\text { I } 3 \cdot 5 \\
98 \cdot 4 \\
94 \cdot 4 \\
80 \cdot 2 \\
-\end{array}$ \\
\hline
\end{tabular}

* One anomalous value for $\mathrm{CO}_{2}$ production accounted for this high value.

Heat production was usually but not invariably lower on the $4^{\text {th }}$ day than on the 3 rd day of fasting. As with sheep (Blaxter, I962), the choice of time after cessation of food at which to measure metabolism is thus arbitrary, since $\mathrm{CH}_{4}$ production in steers, as in sheep, does not cease even after 5 days without food, and metabolism 
and weight decline continuously during fasts. The mean of the values obtained on the $3^{\text {rd }}$ and $4^{\text {th }}$ days of fasting (64th-1 12 th $h$ ) which coincides with respiratory quotients of 0.73 or less have been used in subsequent calculations.

Body size and metabolism. Fig. I summarizes the individual observations on fasting heat production as related to body-weight with Ayrshire cattle or Ayrshire crosses and Black cattle shown separately. All observations were above the line shown in Fig. I, which is the interspecies mean fasting heat production estimated by Brody (1945) to be $70.5 \mathrm{kcal} / \mathrm{kg} W^{0.73} 24 \mathrm{~h}$, where $W=$ body-weight.

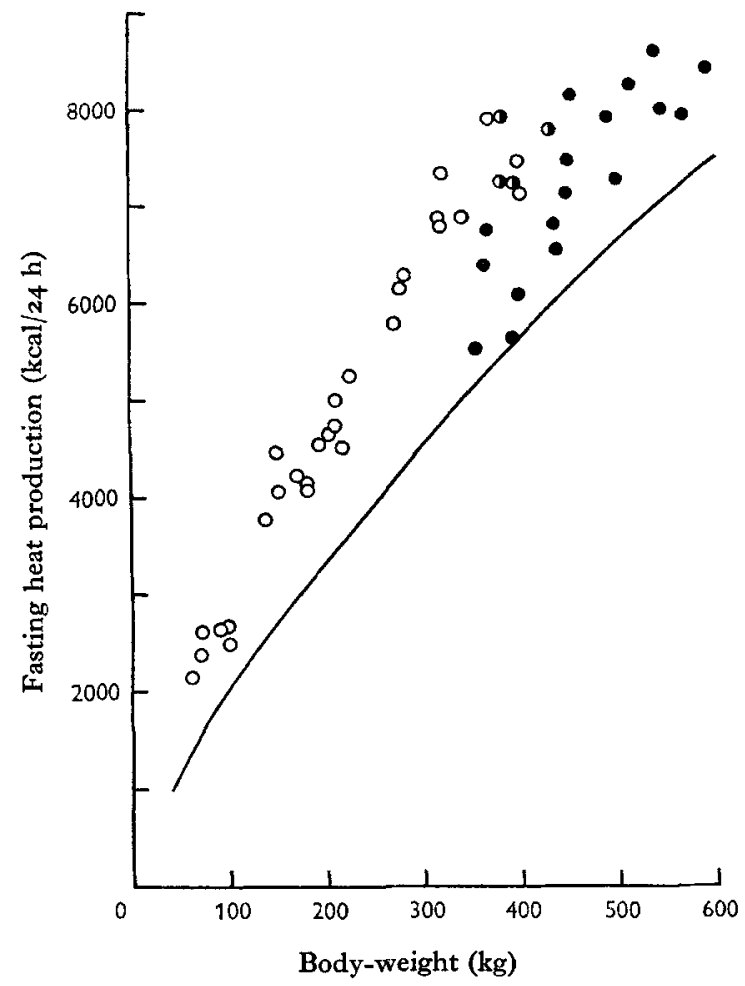

Fig. I. Heat production of fasted steers in relation to their weight. The line is that which relates fasting metabolism to weight in adults of different species calculated according to Brody's (1945) formula: heat production (kcal/24 h) $=70^{\circ} 5$ body-weight $(\mathrm{kg})^{0.78}$. $\mathrm{O}$, Ayrshire cattle; Black cattle of the Aberdeen Angus type; 1 , Ayrshire $\times$ Beef Shorthorn cattle.

With five of the Ayrshire steers fasting metabolism was determined at intervals throughout their lives from $4-8$ months to $2 \frac{1}{2}$ years of age. The linear regressions and $\log -\log$ regressions of fasting metabolism on fasted body-weight of these animals are given in Table 3 ; these demonstrate that metabolism increased with body-weight. All the regressions were statistically significant $(P<0.01)$. The values of $F$, the variance ratio, were with two steers greater for the logarithmic than for the linear regression, and with three other steers the reverse was true. Prediction of metabolism from a logarithmic regression was thus no more precise than prediction from a linear one. 
Fasting heat production calculated from the linear regressions did not differ significantly between animals and the pooled linear coefficient shows that metabolism increased by an average of $16.6 \mathrm{kcal} / 24 \mathrm{~h} \mathrm{~kg}$ weight gain. The pooled logarithmic regression indicates that the metabolism of these steers varied with weight raised to the power $0.68 \pm 0.052$. This value was not statistically different from values of 0.73 or 0.75 which are the powers of weight with which the fasting metabolism of different species varies (Brody, 1945; Kleiber, I961, I965). No systematic error would thus accrue if the results for animals of different weights were compared by expressing them per unit of metabolic body size, that is, body-weight raised either to the power 0.73 or to the power 0.75 , as in Table 4 .

Table 3. Regressions of fasting metabolism (F, kcal/24 h) on body-weight (W, $k g$ ) of five Ayrshire steers

\begin{tabular}{|c|c|c|c|c|c|c|}
\hline \multirow[b]{2}{*}{$\begin{array}{c}\text { Steer } \\
\text { no. }\end{array}$} & \multirow[b]{2}{*}{$\begin{array}{l}\text { Weight } \\
\text { range } \\
(\mathrm{kg})\end{array}$} & \multirow[b]{2}{*}{$\begin{array}{l}\text { No. of } \\
\text { obser- } \\
\text { vations }\end{array}$} & \multicolumn{2}{|c|}{ Linear regression } & \multicolumn{2}{|c|}{ Logarithmic regression } \\
\hline & & & Equation & $\begin{array}{l}\text { Residual } \\
\text { standard } \\
\text { deviation }\end{array}$ & Equation & $\begin{array}{c}\text { Residual } \\
\text { standard } \\
\text { deviation* }\end{array}$ \\
\hline 1 & $\times 37-319$ & 5 & $F=I I I I+I 8.6 \mathrm{~W}$ & $\pm \mathbf{2 8 6}$ & $F=91.6 \quad W^{0.750}$ & \pm 318 \\
\hline 2 & $147-398$ & 6 & $F=20$ & $\circ$ & $F=194.5 W^{0}$ & \pm 475 \\
\hline 3 & $152-39$ & 6 & $=1909+14.8 \mathrm{~W}$ & \pm 263 & $F=133^{\circ} \circ W^{0.678}$ & \pm 217 \\
\hline 4 & & 5 & $F=1083+17 \cdot 1 W$ & \pm 240 & $F={ }_{172.4} W^{0.616}$ & \pm 480 \\
\hline 5 & $74-367$ & 4 & $F=857+19.1 W$ & \pm 135 & $F=86.8 \quad W^{0.758}$ & \pm 304 \\
\hline All & & 26 & $F=1356+\mathrm{r} 6.6 \mathrm{~W}$ & \pm 363 & $F=\mathrm{I} 28 \cdot \mathrm{I} W^{0.683}$ & \pm 394 \\
\hline
\end{tabular}

* Computed from $\Sigma\left(F_{\text {obs }}-F_{\text {calc }}\right)^{2} /(n-2)$, where $n$ is the number of observations and $F_{\text {obs }}$ and $F_{\text {calc }}$ the observed metabolism and that calculated from the logarithmic regression.

The mean fasting $24 \mathrm{~h}$ heat production of the seventeen animals varied from $72 \cdot 9$ to $106 \cdot \mathrm{rkal} / \mathrm{kg} W^{0.73} 24 \mathrm{~h}$, or from 64.5 to $97 \cdot 7 \mathrm{kcal} / \mathrm{kg} W^{0.75} 24 \mathrm{~h}$. The errors attached to values for individuals were obtained from analysis of variance of the results of all the trials. Variation in the metabolism of the same animal from occasion to occasion expressed as a coefficient of variation was $\pm 7.36 \%$ when metabolism was expressed per $\mathrm{kg} W^{0.73}$ and $\pm 7.43 \%$ when expressed per $\mathrm{kg} W^{0.75}$. There was clearly no difference in variation due to choice of reference base. This variation includes all instrumental and analytical error as well as variation of the metabolism of the same animal from occasion to occasion.

Table 4 shows that all the Ayrshire steers had a higher fasting metabolism than the Black steers. The mean values for breed groups given at the foot of Table 4 , obtained by giving the mean for each animal an equal weighting, shows that the difference between metabolism of the Ayrshire and the Black cattle was statistically significant. From Table 4, and more particularly from Fig. I, it is evident that the distribution of bodyweight in the two groups was very different. If, however, only those observations made with animals weighing more than $300 \mathrm{~kg}$ are included, the mean fasting metabolism of the five Ayrshires (two are excluded) was $90 \cdot 4 \pm 2 \cdot 4 \mathrm{kcal} / \mathrm{kg} W^{0.73} 24 \mathrm{~h}$, the mean fasting metabolism of the Black cattle remains unchanged and the difference between Black and Ayrshire cattle is reduced to $9 \cdot 4 \pm 2 \cdot 6 \mathrm{kcal} / \mathrm{kg} W^{0.73} 24 \mathrm{~h}$. This difference was 
statistically significant $(P<0.01)$. The two Ayrshire $\times$ Beef Shorthorn crosses which were within the same weight and age range as the Black cattle also had a higher metabolism than the Black cattle $(P<0.01)$.

Table 4. Fasting metabolism of individual steers. Values are means with their standard errors

\begin{tabular}{|c|c|c|c|c|c|c|}
\hline \multirow[b]{2}{*}{ Steer } & \multirow[b]{2}{*}{ Breed or type } & \multirow[b]{2}{*}{$\begin{array}{c}\text { Body- } \\
\text { weight } \\
\text { range } \\
(\mathrm{kg})\end{array}$} & \multirow[b]{2}{*}{$\begin{array}{c}\text { Age } \\
\text { range } \\
\text { (years) }\end{array}$} & \multirow[b]{2}{*}{$\begin{array}{c}\text { No. of } \\
\text { deter- } \\
\text { minations }\end{array}$} & \multicolumn{2}{|c|}{$\begin{array}{l}\text { Mean fasting } \\
\text { heat production }\end{array}$} \\
\hline & & & & & $\begin{array}{c}\mathrm{kcal} / \mathrm{kg} \\
W^{0 \cdot 73} \\
\text { per } 24 \mathrm{~h}\end{array}$ & $\begin{array}{c}\mathrm{kcal} / \mathrm{kg} \\
W^{0.35} \\
\text { per } 24 \mathrm{~h}\end{array}$ \\
\hline $\mathbf{I}$ & Ayrshire & $137-319$ & $0.7-2.5$ & 5 & $102.4 \pm 3.2$ & $91 \cdot 9 \pm 2 \cdot 9$ \\
\hline 2 & Ayrshire & $147-398$ & $0.7-2 \cdot 5$ & 6 & $98.7 \pm 2.9$ & $88 \cdot 4 \pm 2 \cdot 6$ \\
\hline 3 & Ayrshire & $152-398$ & $0 \cdot 7-2 \cdot 6$ & 6 & $100.6 \pm 2.9$ & $90 \cdot 1 \pm 2 \cdot 6$ \\
\hline 4 & Ayrshire & $74-340$ & $0.3-2 \cdot 0$ & 5 & $97 \cdot 0 \pm 3 \cdot 2$ & $87 \cdot 6 \pm 2 \cdot 9$ \\
\hline 5 & Ayrshire & $74-367$ & $0 \cdot 3-2 \cdot 0$ & 4 & $1000 \pm 3.5$ & $90 \cdot 3 \pm 3 \cdot 2$ \\
\hline 6 & Ayrshire & 63 & $0 \cdot 3$ & $\mathbf{I}$ & $106 \cdot 1 \pm 7^{\circ} 0$ & $97 \cdot 7 \pm 6 \cdot 4$ \\
\hline 7 & Ayrshire & 92 & 0.7 & $\mathbf{I}$ & $96.9 \pm 7 \cdot 0$ & $88 \cdot 6 \pm 6 \cdot 4$ \\
\hline $\mathrm{Kv}$ & Ayrshire cross & $380-392$ & $1 \cdot 8-2 \cdot 4$ & 2 & $98 \cdot 4 \pm 5 \cdot 0$ & $87 \cdot 3 \pm 4 \cdot 5$ \\
\hline $\mathrm{Bg}$ & Ayrshire cross & $379-430$ & $2 \cdot 4-3 \cdot 6$ & 2 & $943 \pm 5.0$ & $83 \cdot 6 \pm 4 \cdot 5$ \\
\hline As & Black* & $490-567$ & $2 \cdot 0-3 \cdot 7$ & 4 & $83.1 \pm 3.5$ & $75 \cdot 5 \pm 3 \cdot 2$ \\
\hline Ay & Black & $450-594$ & $2 \cdot 0-3 \cdot 7$ & 4 & $82 \cdot 8 \pm 3 \cdot 5$ & $73 \cdot 1 \pm 3 \cdot 2$ \\
\hline $\mathrm{C}$ & Black & $36_{3}-36_{5}$ & $2 \cdot 0-2 \cdot 4$ & 2 & $88 \cdot 6 \pm 5^{\circ} 0$ & $78 \cdot 7 \pm 4 \cdot 5$ \\
\hline$F$ & Black & $434-443$ & $2 \cdot 0-2 \cdot 4$ & 2 & $82 \cdot 0 \pm 5 \cdot 0$ & $74 \cdot 5 \pm 4 \cdot 5$ \\
\hline $\mathrm{E}$ & Black & 392 & $2 \cdot 0$ & $\mathbf{I}$ & $72 \cdot 9 \pm 7 \cdot 0$ & $64 \cdot 5 \pm 6 \cdot 4$ \\
\hline $\mathrm{H}$ & Black & $439-454$ & $2 \cdot 0-2 \cdot 4$ & 2 & $83 \cdot 8 \pm 5 \cdot 0$ & $75^{\circ} 9 \pm 4.5$ \\
\hline I & Black & 349 & $2 \cdot 0$ & $\mathbf{I}$ & $77 \cdot 0 \pm 7 \cdot 0$ & $68 \cdot 6 \pm 6 \cdot 4$ \\
\hline $\mathrm{J}$ & Black & 394 & $2 \cdot 0$ & $\mathbf{I}$ & $77 \cdot 5 \pm 7 \cdot 0$ & $68 \cdot 7 \pm 6 \cdot 4$ \\
\hline \multicolumn{7}{|c|}{ Means } \\
\hline & & $100 \cdot 2 \pm 1 \cdot 6 \dagger$ & $90 \cdot 7 \pm x \cdot 51$ \\
\hline & & & & Five Ayrshires weighing more than $300 \mathrm{~kg}$ & $90.4 \pm 2.4 t$ & \\
\hline & \multicolumn{4}{|c|}{ Two Ayrshire crosses } & $96 \cdot 3 \pm 2 \cdot 9 \dagger$ & $85.4 \pm 2 \cdot 91$ \\
\hline & \multicolumn{4}{|l|}{ Eight Black cattle } & $8 \mathrm{I} \cdot 0 \pm \mathrm{I} \cdot 5 \dagger$ & $72 \cdot 4 \pm 1 \cdot 51$ \\
\hline \multirow{2}{*}{\multicolumn{5}{|c|}{$\begin{aligned} \text { Interspecies mean: Brody (r 945) } \\
\text { Kleiber (I 96I) }\end{aligned}$}} & $70 \cdot 5$ & - \\
\hline & & & & & - & $69 \cdot 0 \pm I \cdot 5$ \\
\hline \multicolumn{5}{|c|}{ Sheep, 3 years of age (Blaxter, x962) } & $5^{8 \cdot 5 \pm I \cdot 3}$ & $54 \cdot 1 \ddagger$ \\
\hline
\end{tabular}

Protein metabolism. The proportion of the total loss of energy from the body during fasting which derived from oxidation of protein was $26 \cdot 4 \pm \mathrm{I} \cdot 2 \%$ for the seven Ayrshire cattle, $23.0 \pm 2 \cdot 1 \%$ for the two crosses and $23.3 \pm 1 \cdot 1 \%$ for the eight Black cattle. These means did not differ significantly one from another nor was the regression of the percentage of the loss of energy from the body which was derived from protein on metabolism per $\mathrm{kg} W^{0 \cdot 73}$ significant statistically. The slightly higher value for Ayrshire cattle compared with Black cattle was not due to the fact that the Ayrshires were younger. In six experiments in which Ayrshire cattle, weighing Ioo kg or less, were fasted, $26.7 \%$ of the total energy loss was accounted for by protein oxidation. In six experiments in which Ayrshire cattle weighing over $300 \mathrm{~kg}$ were fasted, the mean proportion accounted for by protein was $25.5 \%$. The small apparent fall was not statistically significant. It appears therefore that on average $24.5 \pm 0.8 \%$ of the energy lost from the bodies of the cattle during fasting was derived from protein oxidation. 
In similar trials with sheep the loss of energy derived from protein, expressed as a percentage of the total loss of energy, was $23.8 \pm 1 \cdot 5$ (Blaxter, I962), a value not significantly different from that noted with cattle.

\section{DISCUSSION}

The determinations of the fasting metabolism of the seventeen steers show that relative to generalizations made with a wide range of other species the steers had a high fasting metabolism for their size. Previous investigations with sheep (Blaxter, r 962) showed that wether sheep aged more than 2 years had a low fasting metabolism of

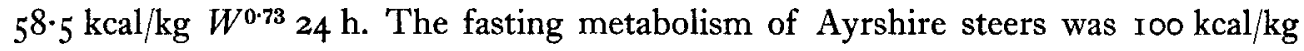
$W^{0.73} 24 \mathrm{~h}$ and that of Black steers $8 \mathrm{r} \mathrm{kcal} / \mathrm{kg} W^{0.73} 24 \mathrm{~h}$. The mean metabolism of all species as estimated by Brody (1945) was $70.5 \mathrm{kcal} / \mathrm{kg} W^{0.73} 24 \mathrm{~h}$. This estimate, however, differs slightly from that determined by Kleiber (1961) which was $69 \cdot 5 \mathrm{kcal} \mid \mathrm{kg}$ $W^{0.75} 24 \mathrm{~h}$.

Kleiber's equation predicts the metabolism of a $50 \mathrm{~kg}$ animal to be $7 \%$ greater and of a $500 \mathrm{~kg}$ animal to be I $2 \%$ greater than does the equation of Brody. When Kleiber's equation with its slightly larger coefficient of $W$ is used as a reference base, the difference in the metabolism of sheep and cattle relative to an interspecies mean is slightly reduced. To obliterate the difference between them entirely, metabolism as between species would have to vary with a power of body-weight greater than 0.9 . No investigations of the relation of the metabolism to weight in a series of different species differing in size suggest that the interspecies exponent of $W$ can approach a value of 0.9. The conclusion that relative to all species sheep have a low fasting metabolism and cattle a high one appears, therefore, to be correct.

The evidence that the fasting metabolism of different breeds of cattle may differ supports results obtained by Hashizume et al. (1962). They found the mean fasting metabolism of five Japanese Holstein cattle to be $73^{\cdot} \mathrm{r} \mathrm{kcal} / \mathrm{kg} W^{0 \cdot 75} 24 \mathrm{~h}$ and of four Japanese Black cattle $5^{1} \cdot 5 \mathrm{kcal} / \mathrm{kg} W^{0.75} 24 \mathrm{~h}$, the difference being statistically significant. The former value, which is corrected to $24 \mathrm{~h}$ lying down, agrees with a mean value reported by Flatt \& Coppock $(1963)$ of $73.5 \mathrm{kcal} / \mathrm{kg} W^{0.75} 24 \mathrm{~h}$ with six Holstein cows in the USA. Earlier Ritzman \& Benedict (1938) had noted that Jersey cows had a higher fasting metabolism than Holstein cows. Brody's (1945) extensive metabolic investigations suggest, however, that the Jersey cow has if anything a lower metabolism than the Holstein. In addition, he found no large difference between the basal metabolism of Holstein cattle and beef cattle in the United States.

Ritzman \& Benedict (1938) drew attention to a considerable variation in the fasting metabolism of cows and steers. In their experiments the heat production of individual animals from occasion to occasion certainly varied more than it did in ours. 


\section{REFERENCES}

Benedict, F. G. \& Ritzman, E. G. (I 927). Publs Carnegie Instn, no. 377.

Blaxter, K. L. (1962). Br. F. Nutr. 16, 615.

Blaxter, K. L. \& Wainman, F. W. (196ra). F. agric Sci., Camb., 56, 81.

Blaxter, K. L. \& Wainman, F. W. (г96 г b). F. agric. Sci., Camb., 57, 4 I 9.

Blaxter, K. L. \& Wainman, F. W. (1964). F. agric. Sci., Camb., 63, 113.

Blaxter, K. L., Wainman, F. W. \& Davidson, J. (I 966). Anim. Prod. 8. (In the Press.)

Brody, S. (1945). Bioenergetics and Growth. New York: Reinhold Publishing Corp.

Cochrane, D. C., Fries, J. A. \& Braman, W. W. (1925). J. agric. Res. 31, 1055.

Flatt, W. P. \& Coppock, C. E. (1963). F. Dairy Sci. 46, 638.

Forbes, E. B., Fries, J. A., Braman, W. W. \& Kriss, M. (1926). F. agric. Res. 33, 591.

Forbes, E. B., Kriss, M. \& Braman, W. W. (1927). F. agric. Res. 34, 167.

Forbes, E. B., Swift, R. W., Bratzler, J. W., Black, A., Wainio, W. W., Marcy, L. F., Thacker, E. J. \& French, C. E. (194I). Bull. Pa agric, Exp. Stn, no. 415.

Grouven, H. (1864). Physiologisch-chemische Fütterungsversuche. Zweiter Bericht über die Arbeiten der agrikulturchemischen Versuchsstation zu Salzmünde, Berlin.

Hashizume, T., Kaishio, Y., Ambo, S., Morimoto, H., Masubuchi, T., Abe, M., Horii, S., Tanaka, K., Hamada, T, \& Takahashi, S. (1962). Bull. natn. Inst. agric. Sci., Tokyo, Ser. G no. 2 I. (In Japanese.)

Hashizume, T., Morimoto, H., Masubuchi, T., Abe, M., Horii, S., Hamada, T., Tanaka, K., Takahashi, S., Kaishio, Y. \& Ambo, S. (1964). Spec. Rep. natn. Inst. Anim. Ind., Chiba, no. 2.

Kleiber, M. (1961). The Fire of Life, New York: Wiley.

Kleiber, M. (1965). Publs Eur. Ass. Anim. Prod. no. 11, p. 427.

Kleiber, M., Regan, W. M. \& Mead, S. W. (I945). Hilgardia, I6, 5 I 1.

Mitchell, H. H., Hamilton, T. S. \& Haines, W. T. (r940). F. agric. Res. 6r, 847.

Mitchell, H. H., Hamilton, T. S. \& Haines, W. T. (1941). F. Nutr. 22, 54I.

Mitchell, H. H., Hamilton, T. S., McClure, F. J., Haines, W. T., Beadles, J. R. \& Morris, H. P. (1932). F. agric. Res. 45, 163.

Ritzman, E. G. \& Benedict, F. G. (1938). Publs Carnegie Instn, no. 494.

Robertson, A., Paver, H., Barden, P. \& Marr, T. G. (I960). Res. vet. Sci. I, I 7.

Wainman, F. W. \& Blaxter, K. L. (r958). Publs Eur. Ass. Anim. Prod. no. 8, p. 80. 